\title{
On the Study of Cross-cultural Assimilation in Business Negotiation
}

\author{
Wang Yu \\ College of Literal Arts Changchun University of Science and Technology
}

Keywords: cultural factors; business negotiation; conflict; assimilation.

\begin{abstract}
As world economic and trade are becoming globalized, they are now among the least concerns for any organization that has decided to go to the world. Today, international business people increasingly find themselves working in multi-cultural environment, dealing with real differences in everything from communication styles to social etiquette to core values. From the cultural perspective, this paper has put emphasis on several main factors affecting international business negotiation, such as language, social customs and habits, time etc. Cultural differences can influence business negotiations in significant and unexpected ways. So knowledge of these factors may help a negotiator understand a counterpart from another culture and anticipate possible friction and misunderstandings, by extension, take initiative in negotiations.
\end{abstract}

\section{Introduction}

With the quick development of economic globalization, economic and trade exchange in the world becomes more and more frequent and intimate. So it results in more and more communication and cooperation with each other.The international business negotiations are affected greatly by political, economic, cultural and other factors, among which cultural factors are the most difficult one to control, which results in different negotiation styles of business people from various countries or districts. Therefore, it is crucial to understand the cultural factors in international business negotiations and to know further business negotiating styles in various places. The impacts of culture on negotiations have intrigued both scholars and practitioners. Their research and observations indicate fairly clearly that negotiation practices differ from culture to culture, which can influence "negotiating style"----the way persons from different cultures conduct themselves in negotiating sessions.

One important characteristic of international business negotiation is cultural difference. Because of cultural differences, it leads to cultural clash or even conflict. Therefore, large quantity of negotiations will fail. As American scholar Paul A. Herbeg pointed out "Both negotiating parties want to come to a successful agreement, but over 2/3 negotiating efforts between American and Japanese fail. The obstacle of a successful agreement comes from cultural factors, not economic or legislative elements. Because both negotiating sides observe the other party from their own national advantage and experience, each party also cannot understand why the negotiation fails. The lack of some related cultural knowledge will make them consider the other party as 'exotic' or 'unnatural'." Chinese and western cultures both have their own historical origin. Their deep structure is also not a train on the same orbit. The divergence of the two cultures will surely be obstacle of way of cultural, political, and economic communication. Cultural difference affects not only the use and understanding of various words and actions of both negotiating parties, but also their way of thinking and concepts of value. Even they'll take these concepts to the negotiating table unconsciously to make negotiation complex. Of course, a successful negotiation demands direct information exchange unimpeded. While cultural differences always lead to impedance of information exchange, different countries have their particular local customs and social values. People should pay special attention to them.

Why is cross-cultural knowledge and understanding so important? The American statesman and inventor Benjamin Franklin wrote that time is money. Global-trotting business people would add that being aware of cultural differences and sensitivities is money too. Failing to grasp the subtleties that lie beyond such public cultural displays like greeting rituals and seating arrangements can make the 
difference between truly successful international business transactions one that fails to connect. Culture affects the most basic from decision-making to management style.

\section{Cultural Differences}

There is no cultural right or wrong, just differences. We must not make value judgments as to whether or not cultural behavior is good or bad, better or worse.

Once upon a time there was a great flood, and involved in the flood were two creatures, a monkey and a fish. The monkey, being agile and experienced, was lucky enough to scramble upon a tree and escape the raging waters. As he looked down from his safe perch, he saw the poor fish struggling against the swift current. With the very best of intentions, he reached and lifted the fish from the water. The result was inevitable. (Adams, 1969)

It is wrong to assume that people in different cultures think, feel and act in the same way. Ignorance of cultural differences could end with fatal consequences, as dramatized so vividly in the story of the monkey and the fish.

International business dealings, ignorance of cultural difference is not only unfortunate, but also bad business. Sensitivity to cultural difference is crucial to successful international business operations. Ignorance of cultural differences could end in disastrous business blunders. (There are many documented cases in which multi-nationals have failed to understand fully the foreign cultural environment, for an interesting account of such blunders.)

This means to provide business people with a better grasp of the impact of the socio-cultural environment of international business, and suggestions for how to better conduct their business in a multicultural environment.

Every nation in the world has its own cultural specialty. Generally speaking, there exist a few big cultural circles. For instance, western countries belong to Christian cultural circle, southeast Asia belongs to Buddhism, Arab belongs to Islam, Japan and South-Korea belong to Han cultural circle etc.. During negotiation, one should respect these different cultural contents and their special beliefs, or it will affect or even destroy the negotiating process.

There is no best method of cultural analysis appropriate for all business decision. Assessing the cultural environment of international business depends largely on the type of business and the international activities involved. One practical approach is to break down the broad area of the socio-cultural environment into its various elements and to study each element in detail, (for example, lists five dimensions to culture: material culture; social institutions; mankind and the Universe; aesthetics; and language and communication). It should be noted, however, that culture is not simply a group of unrelated elements, but that the different facts of culture are intricately intertwined (Cateora, 1990) and must be viewer integrated complex whole. An employee's behavior, for example, or a customer's reaction cannot be fully explained by a simple reference to certain aspects of the cultural environment influencing their attitude such as language, religion, social structure and so on. It is essential for business people to understand the reasons and motivations behind such a behavior or reaction. An overall approach to the analysis of the cultural environment is that culture is understood as a system composed of parts that are related to other parts, which mutually influence and adjust to each other, through a process of cooperation, competition, conflict and accommodation.

\section{Cultural Obstacles in Negotiation}

Culture is made up of language, aesthetic standard, concept of value, religious belief and material civilization. These factors are a dispensable whole. They connected with each other complicatedly. So negotiators must study multi-cultural factors in order to adapt cultural characteristics of the other party, and make the opposite party easy to accept your negotiating stipulations.

When you negotiate with people from different countries or districts, Because of different cultural differences, there must be certain obstacles in communication. 


\subsection{Traditional obstacles}

Now, China has established diplomatic relations with most of countries in the world. Every country has its own customs and taboos. It is a big obstacle when negotiators communicate with each other from various countries. It will hinder people's normal information exchange. For instance, Chinese shake hands to show friendly. If you shake hands with Germans, they will feel nervous; Chinese eat with chopsticks, while westerners use forks and knives. These usual living customs can affect negotiating communication. Another example, westerners consider that No. "13" is not auspicious. Under no circumstances, will they try to avoid the number. If you make an appointment on thee date of $13^{\text {th }}$ day, at 13 o'clock, on $13^{\text {th }}$ floor or Room 13 to discuss something, the discussion will be surely unpleasant. Even though it is a thoughtful communicating plan, it also will fail.

Therefore, if you want the communication to reach an expectable objective, you must know very well various foreign habits and customs and learn how to accommodate you to the other party in social communicating circumstances. It will help you remove traditional obstacles in business negotiating communication.

\subsection{Obstacles of subjective element}

In reality, there exist many obstacles of subjective element, which hinder information exchange and people's communication. The following are the main manifestations:

(1) The obstacles of cognition

It is generally personal divergence for different cognition on the same thing. Therefore, it affects information exchange and also the cooperation and negotiation of negotiating parties. No matter what negotiating form or what communicating subject you take, the divergence will make you feel suppressed. Even the other party will doubt you cheat him and keep highly alert any time.

(2) The obstacles of understanding

Sometimes, one is accordance with the other, but the understanding on the same thing is different. Thus, it will also affect information exchange. Chinese are sensitive about their reputation. They also pay attention to others' reputation. When communicating with guests, they seldom use embarrassing negative "no"; Americans do not care about it. They don't think the business is over If you don't use direct answer to reply on them. Negotiators don't understand or overcome the obstacle effectively, and it will also affect communication.

\section{Conclusion}

Culture-along with many other variables-often affects international negotiations. The paper offers a unique contribution by focusing on the distinctive impact of culture, both in creating unexpected opportunities for dispute settlement and in imposing obstacle to agreement.

Culture is the most challenging elements of the international business. This system of learned behavior patterns of characteristics of the members in a given society is constantly shaped by a set of dynamic variables: language, religion, values and attitudes, manners and customs, education and social institutions. To cope with this system, an international negotiator needs both the factual and interpretive knowledge of culture. To some extent, the factual knowledge can be learned; it interpretation comes only through experiences.

The most complicated problem in dealing with cultural environment stem from the fact that one cannot learn culture-one has to live in it. But as long as you play emphasis on cultural factors, and whatever you do, you'd better first think about it, you can overcome these difficulties.

\section{References}

[1] Curry, Jeffery E, A Short course in International Negotiation [M]. World Trade Express, 1999.

[2] Jeswald W. Salacuse, Culture and Negotiation [A] .Newburry Park: Sage Publications.2006.

[3] Mitchell Charles, A short Course in International Business Culture [M]. World Trade Express, 2001. 
[4] Scott Snyder, Negotiating on the Edge: patterns in North Korea's Diplomatic Style, World Affairs, 2009.

[5] http://www.findarticle.com/cf. 